\title{
STEAMFLOW RESPONSE AND SEDIMENT YIELD AFTER FARMLAND ABANDONMENT: RESULTS FROM A SMALL EXPERIMENTAL CATCHMENT IN THE CENTRAL SPANISH PYRENEES
}

\author{
N. Lana-Renault ${ }^{2,1}$, D. RegüÉs ${ }^{1}$, E. NAdal-Romero ${ }^{3,1}$, M. P. Serrano-Muela ${ }^{1}$ \\ \& J. M. GARCÍA-RUIZ ${ }^{1}$ \\ 1. Instituto Pirenaico de Ecología, CSIC, Campus de Aula Dei, Apartado 13034, 50080-Zaragoza, \\ Spain. \\ 2. Physical Geography Research Institute, Utrecht University, The Netherlands. \\ 3. Dep. Earth and Environmental Sciences, Physical and Regional Geography Research Group, \\ K.U.Leuven. Celestijnenlaan 200 E, P. O. box 3001.Heverlee, Belgium. \\ e-mail: humberto@ipe.csic.es
}

\begin{abstract}
A small catchment affected by agricultural practices in the past, then progressively abandoned and naturally re-vegetated was monitored in the central Spanish Pyrenees. The results obtained over a 9-year period revealed the complexity of its hydrological and geomorphological behaviour. Several runoff generation processes can occur at the same time and in different parts of the catchment, depending on the water reserves conditions and rainfall characteristics. Sediment response is mainly controlled by the spatial and temporal dynamics of water and sediment contributing areas within the catchment. The sediment output illustrates the complexity of the geomorphic response of mountain environments modified by past farmland activities.
\end{abstract}

Keywords: Runoff generation; suspended sediment-discharge relationships; sediment balance; sub-Mediterranean catchment; central Spanish Pyrenees.

RESUMEN.- Se presenta una sintesis de la investigación realizada en una pequeña cuenca experimental afectada por una intensa actividad agraria en el pasado y sujeta a un proceso de revegetación natural en la actualidad en el Pirineo Central. Los principales resultados obtenidos demuestran su complejo comportamiento hidrogeomorfológico. El análisis de la información hidrológica sugiere que diferentes procesos dominantes de generación de escorrentía pueden ocurrir de manera simultánea en diferentes áreas de la cuenca, en función del estado de humedad de 


\section{N. LANA, D. REGÜÉS, E. NADAL, M. P. SERRANO \& J. M. GARCÍA}

la misma y de las características de la precipitación. La respuesta sedimentológica
está principalmente controlada por la dinámica espacio-temporal de las áreas fuente
de escorrentía y de sedimento. La exportación de sedimento ilustra la complejidad de
la respuesta geomorfológica en los ambientes de montaña afectados por actividades
agrarias en el pasado.

Palabras clave: Generación de escorrentía; relaciones sedimento en suspensión y caudal; balance de sedimentos; cuenca sub-mediterránea; Pirineo Central.

\section{Introduction}

Mediterranean mountains were affected by large land use changes during the last centuries. In the case of the Spanish Pyrenees, human pressure was very intense until the middle of the 19th century, with deforestation, cultivation of steep slopes, frequent man-induced fires and overgrazing (LASANTA 1988; GARCÍA-RUIZ \& LASANTA, 1990). Posterior depopulation, especially since the 1960's, resulted in progressive farmland abandonment. As a consequence, most of the hillslopes became marginal and subject to vegetation regrowth (TAILLEFUMIER \& PIÉGAY, 2003; VICENTESERRANO et al., 2004; LASANTA \& VICENTE-SERRANO, 2007), with significant impact on runoff production, and on soil erosion and conservation. This is of particular importance in Mediterranean basins, where water management relies on runoff generated in mountain areas (LÓPEZMORENO et al., 2008). In the central Spanish Pyrenees, the hydrological and geomorphic consequences of such a large land-cover change have been studied by The Department of Geo-environmental Processes and Global Change (Pyrenean Institute of Ecology, CSIC). Results from plots through small catchments and regional basins point to a general reduction in both overlandflow and sediment yield, and an increase in channel incision processes (GARCÍA-RUIZ et al., submitted).

This paper deals with the investigations carried out at the small catchment scale. In this regard, small experimental catchments possess many advantages in conducting hydrology-based studies: i) they tend to be relatively homogeneous in such a away that they can usually be considered as representative of a certain land use or plant cover, ii) their small size enables the installation and relatively simple maintenance of different measurement devices, iii) the acquisition and analysis of detailed information enables the interpretation of hydrological processes and the elaboration of 
water and sediment balances, finally, iv) this information is essential to validate hydrological and sediment-transport models.

Here we summarise the main results of the research concerning the hydrological and sedimentological response of a small catchment in the central Spanish Pyrenees, affected in the past by intense agricultural practices, then progressively abandoned and naturally colonized with shrubs and forest. The aim of this review is to emphasize on the fact that traditional land uses and their progressive abandonment have introduced heterogeneity in the landscape, increasing the complexity of the hydrological and erosion/sediment transport process involved in mountain environments.

\section{Study area}

The Arnás catchment $\left(2.84 \mathrm{~km}^{2}\right)$ is located in the headwaters of the Aragón River, central Spanish Pyrenees, between 900 and 1400 m a.s.l. (Figure 1a). Mean annual precipitation over the water years (October to September) from 1999 to 2007 was about $929 \pm 198 \mathrm{~mm}$, most of which was concentrated in autumn and spring; intense short-duration convective storms were relatively frequent in summer.

The bedrock of the catchment is Eocene flysch, with alternating sandstone and marl layers sloping northward. The $\mathrm{W}$-E orientation of the ravine results in a strong contrast between the south- and north-facing slopes, the former being much steeper than the latter. The gentler, north-facing slope is marked by an undulating topography with old scars and stable deep mass movement deposits. The south-facing slope is characterized on the upper parts by recent and relatively active debris flows which are disconnected from the drainage network. In the north-facing slope Haplic Kastanozems and Haplic Phaeozems predominate. These are brown and deeper soils $(50$ to $>75 \mathrm{~cm}$ ) with high content of organic matter. In the south-facing slope, shallow and compact soils, showing signs of major degradation (NAVAS et al., 2005), are developed on unconsolidated materials (mostly Rendsic Leptosols and Calcaric Regosols). Sediment sources were mapped through field surveys which indicate that the main areas contributing sediment are (Figure 1b): i) the bare sections of the taluses flanking the main stream where the lack of vegetation and the occurrence of small slumps suggest that they are permanently eroded (GONZÁLEZ et al., 1997), ii) patches of land affected by severe sheet-wash erosion and trails related to current-day grazing activity, spread mostly across the steep south-facing slope, and iii) the unpaved and deteriorated road on the north-facing slope. The main channel is narrow, partially incised and flanked by almost vertical cliffs in the middle stretch, 
and totally covered with coarse material derived from the flysch lithology. As in most of the rivers in the area, this is probably the legacy of past decades of cultivation and overgrazing in the catchment (BEGUERÍA et al., 2006).

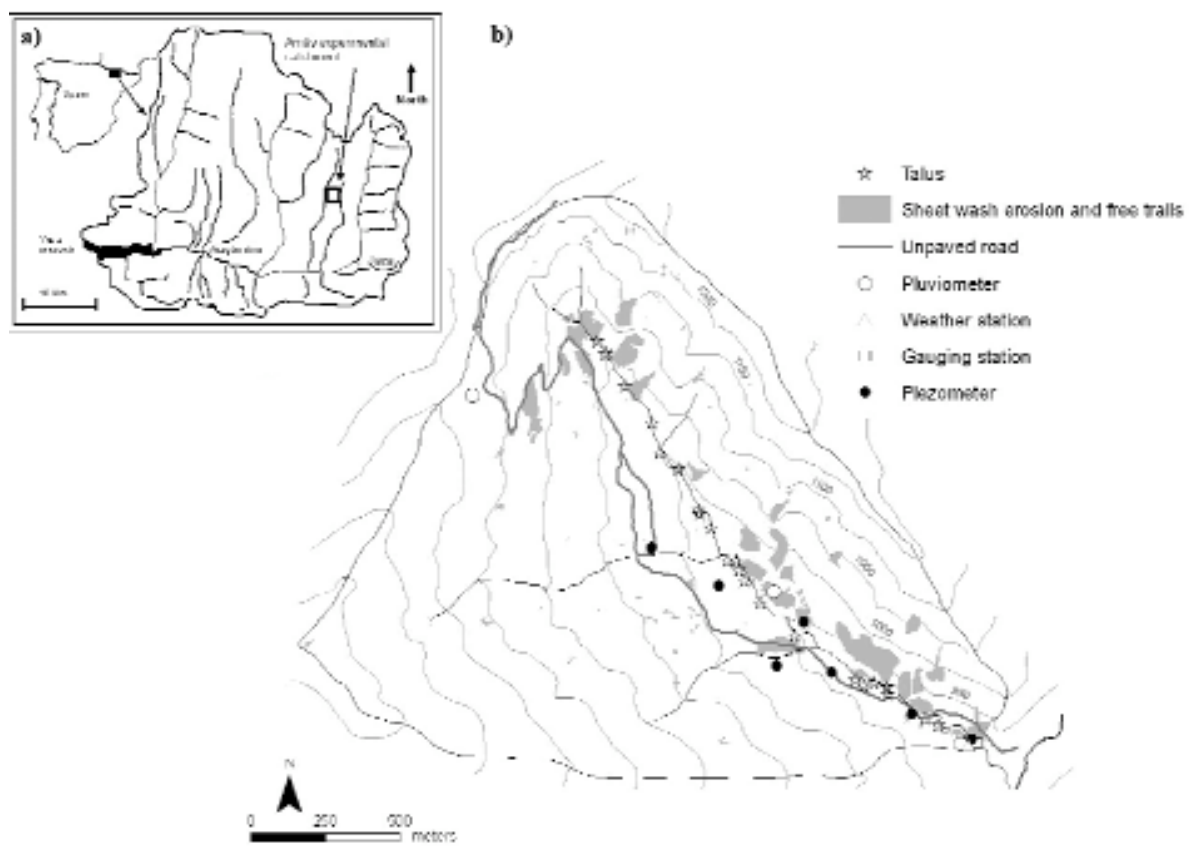

Figure 1. a) Location of the Arnás cathment and b) the Arnás catchment showing the main sediment sources, and the sites of the main monitoring instruments.

The catchment is representative of the mid-altitude Mediterranean mountain environment and land management evolution, as it was totally cultivated with cereal crops in non-terraced fields until the middle of the 20th century, then progressively abandoned and affected by plant recolonization including Genista scorpius, Echinospartum horridum, Juniperus communis, Rosa gr. Canina and Buxus sempervirens. At present (Photo 1), the north-facing slope has dense vegetation cover with large areas of Pinus sylvestris and Quercus faginea. In contrast, the steeper and sunnier south-facing slope is characterized by poorly developed open shrub cover. Parts of the valley floor are covered by herbaceous vegetation, indicating more recent farmland abandonment. 


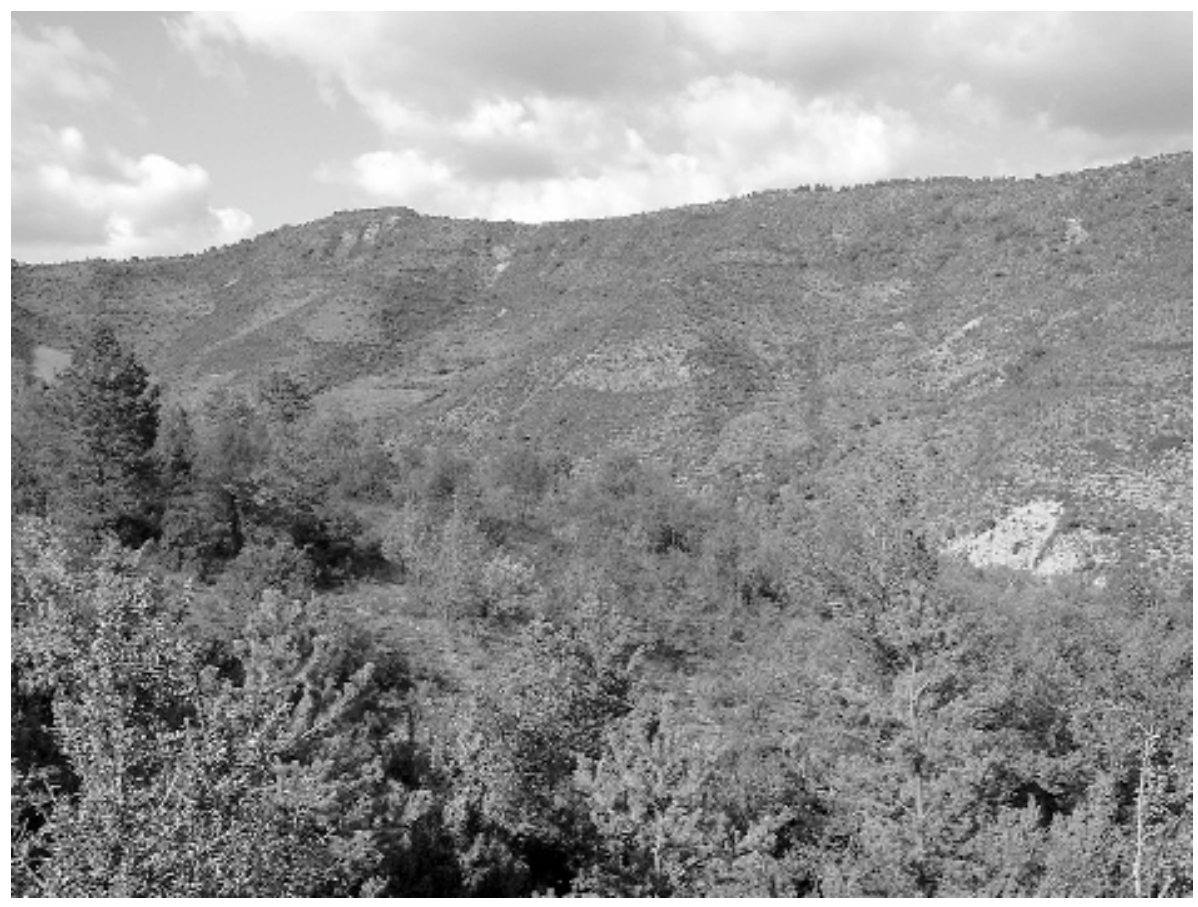

Photo 1. A general perspective of the Arnás catchment. The north-facing slope has dense vegetation cover, whereas the south-facing slope (in the background) is covered by poorly developed shrubs, and still shows the limits of the old abandoned fields. On the right, a bare section of a talus flanking the main stream is evident.

\section{Equipment and methods}

The Arnás catchment was equipped in 1995 with a pluviometer, a complete weather station and gauging station located at the outlet of the catchment, at which discharge, solutes and suspended sediment concentrations were recorded continuously. At present, rainfall is collected using three tipping buckets installed along the main stream (Figure 1b). Rainfall data at 5-min steps are obtained from the original data. At the gauging station, the water level is measured using an ultrasound sensor and a water pressure sensor. The suspended sediment concentrations are obtained using a turbidity meter, previously calibrated in the laboratory using material from the catchment. Solutes are continuously measured with a conductivity meter. All sensors are connected to data loggers recording average data every 
$5 \mathrm{~min}$. In addition, suspended sediment and solutes are recorded during floods with an automatic water sampler. Bedload transport is estimated volumetrically with a $0.7 \mathrm{~m}^{3}$ sediment trap, located immediately upstream of the flume, and a large profilometer to evaluate coarse sediment accumulation upstream of the trap. Seven piezometers were installed at various distances from the main channel and in areas where field observations indicated significant saturation dynamics. In each piezometer, the depth to the water table is continuously recorded using pressure sensors, and average values are recorded every $20 \mathrm{~min}$.

Here we considered rainfall, streamflow and suspended sediment transport data for the 9 water years (October to September) from 1999 to 2007. The identification of floods and the hydrograph separation (into storm-flow and base flow components) followed the approach described in GARCÍARUIZ et al (2005) and LANA-RENAULT et al (2007a). The evolution of the water-table depth was studied at different locations from November 2003 to October 2007 (4 water years). Information on bedload transport was punctually analysed at the event scale for 2 water years.

\section{Results and Discussion}

\subsection{The streamflow response}

Mean annual runoff during the 1999-2007 period was $260 \pm 128 \mathrm{~mm}$, which represents $28 \%$ of the annual rainfall. Figure 2 shows a typical seasonal evolution of daily rainfall, runoff and mean water table depth, together with its standard deviation, which is indicative of the degree of variability between different measurement sites. Based on the data recorded for the water year 2005/06 (Fig. 2), LANA-RENAULT et al. (2007a) differentiated three main periods in the evolution of the water table dynamics, with a dry period in summer followed by a progressive rise in piezometric levels during the autumn wetting-up period and a saturation period during winter when the water table was close to the surface. Spatial variability in the water table was low within the catchment during the wet period, but increased significantly during the wetting-up and drying-down periods. Figure 2 also shows the marked seasonality on the runoff response, strongly dependant on the dynamics of the water table. Highs flows were concentrated at the end of the autumn and especially in spring, when rainfalls were larger and more frequent, and the water reserves were completed. However, the Figure shows that under dry conditions, intense rainstorms also produced high increment 
in discharge, as illustrated by the event on $23^{\text {rd }}$ September. Thus, catchment moisture condition played a major role on the streamflow response, but it was not a determinant factor, suggesting that several mechanisms may produce hydrological response in the catchment.

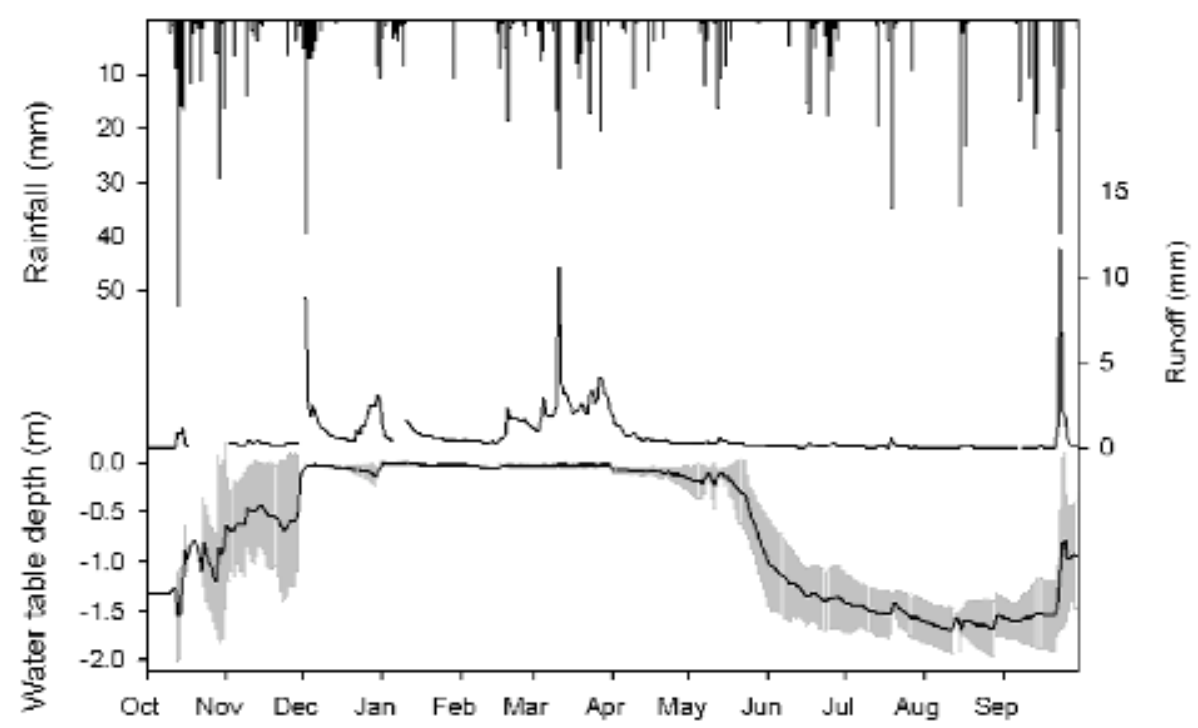

Figure 2. Mean daily rainfall, runoff and water-table depth throughout the hydrological year 2005-2006. Error grey bars show the standard deviation.

A sample of 79 floods was selected over the duration of the study period. The storm-flow coefficient ranged from 0.01 to 0.43 , with a median value of 0.1. Peak flow discharges varied from 20 to $1511 \mathrm{l} \mathrm{s}^{-1} \mathrm{~km}^{-2}$. A return period of 2.5-5 years was empirically estimated for such a maximum peak flow discharge, suggesting its relative frequency. By analyzing the relationships between the storm-flow coefficient, the peak flow and other hydrological variables, GARCÍA-RUIZ et al. (2005) and LANA-RENAULT et al. (2007a) demonstrated the influence of rainfall characteristics and catchment moisture conditions in controlling the hydrological response of the catchment. Table 1 shows that the storm-flow coefficient and the rainfall depth were positively correlated, although the data were somewhat scattered $(R=0.29)$. A stronger correlation $(R=0.38)$ was found between the storm-flow coefficient and the base flow discharge, which is an indicator of the pre-event wetness catchment condition. Rainfall intensity did not seem to play a major role on the storm- 
flow coefficient. However, the absence of a significant correlation at the event scale, when considering the catchment as a whole, does not indicate that rainfall intensity is not locally relevant (e.g., on areas with low vegetation cover). GALLART et al. (2005) reported the importance of rainfall intensity in terms of favouring the occurrence of infiltration excess runoff over localized areas that were devoid of vegetation. In this way, the correlation between the peak flow, and rainfall and rainfall intensity presented relatively high coefficients ( $R=0.66$ and 0.52 , respectively), suggesting their strong influence on the discharge increment.

Table 1. Linear correlation coefficients among storm-flow coefficient (RC), peak flow discharge $\left(Q_{\max }\right)$, and other variables describing the characteristics of the events: rainfall depth $(P), 5-\mathrm{min}$ rainfall intensity (IP5), and base flow at the start of the event $\left(\mathrm{Q}_{0}\right)$. The correlations were considered significant at the 0.05 level $\left({ }^{*}\right)$ and 0.01 level $\left(^{* *}\right)$.

\begin{tabular}{|lccc|}
\hline & $P(\mathrm{~mm})$ & $I P 5\left(\mathrm{~mm} \mathrm{~h}^{-1}\right)$ & $Q_{0}\left(1 \mathrm{~s}^{-1} \mathrm{~km}^{-2}\right)$ \\
\hline $\mathrm{CE}$ & $0,29^{*}$ & $-0,08$ & $0,38^{* *}$ \\
$\mathrm{Q}_{\max }\left(1 \mathrm{~s}^{-1} \mathrm{~km}^{-2}\right)$ & $0,66^{* *}$ & $0,52^{* *}$ & $-0,05$ \\
\hline
\end{tabular}

\subsection{The suspended sediment response}

Figure 3 shows the relative seasonal contributions to precipitation, runoff and suspended sediment yield, aggregated for the 9-years period, and the number of floods recorded in each season (autumn, winter, spring and summer). As reported in the previous section, autumn and spring registered the higher contributions from rainfall and runoff, though a changing relationship among these two variables can be observed from autumn to spring. It is interesting to observe that similar rainfall and a similar number of floods produced about 2-fold higher runoff in spring than in autumn. Such seasonal differences may be related to the fact that at the beginning of the water year (early autumn) most of the incoming rainfall is used to recharge soil moisture and groundwater. Accordingly to this hydrological pattern, suspended sediment was largely transported during spring, with a contribution of about $53 \%$ of the total output, whereas during autumn the contribution was about $28 \%$. Rainfall was moderate in winter, and the suspended sediment yield and runoff were moderate to low, despite the substantial number of floods recorded, indicating that they were of low magnitude. It is notable that the summer produced the same relative suspended sediment yield than the winter, despite of the limited rainfall and 
streamflow response (in terms of both runoff contribution and number of floods). The summer high sediment yields were usually related to the occurrence of a small number of very intense floods (e.g. in June 2000 a single flood produced more than $40 \mathrm{Mg} \mathrm{km}-2$ ). The importance of more intense and less frequent events for catchment sediment output was already reported in Arnás (LANA-RENAULT \& REGÜÉS, 2009) and in many Mediterranean areas (REGÜÉS et al., 2000; GONZÁLEZ-HIDALGO et al., 2007; SOLER et al., 2007; NADAL-ROMERO et al., 2008). LANA-RENAULT \& REGÜÉS (2009) observed that only about $15 \%$ of events, representing $30 \%$ of the total rainfall recorded at the event scale, produced about $50 \%$ of the runoff and $75 \%$ of the suspended sediment load.

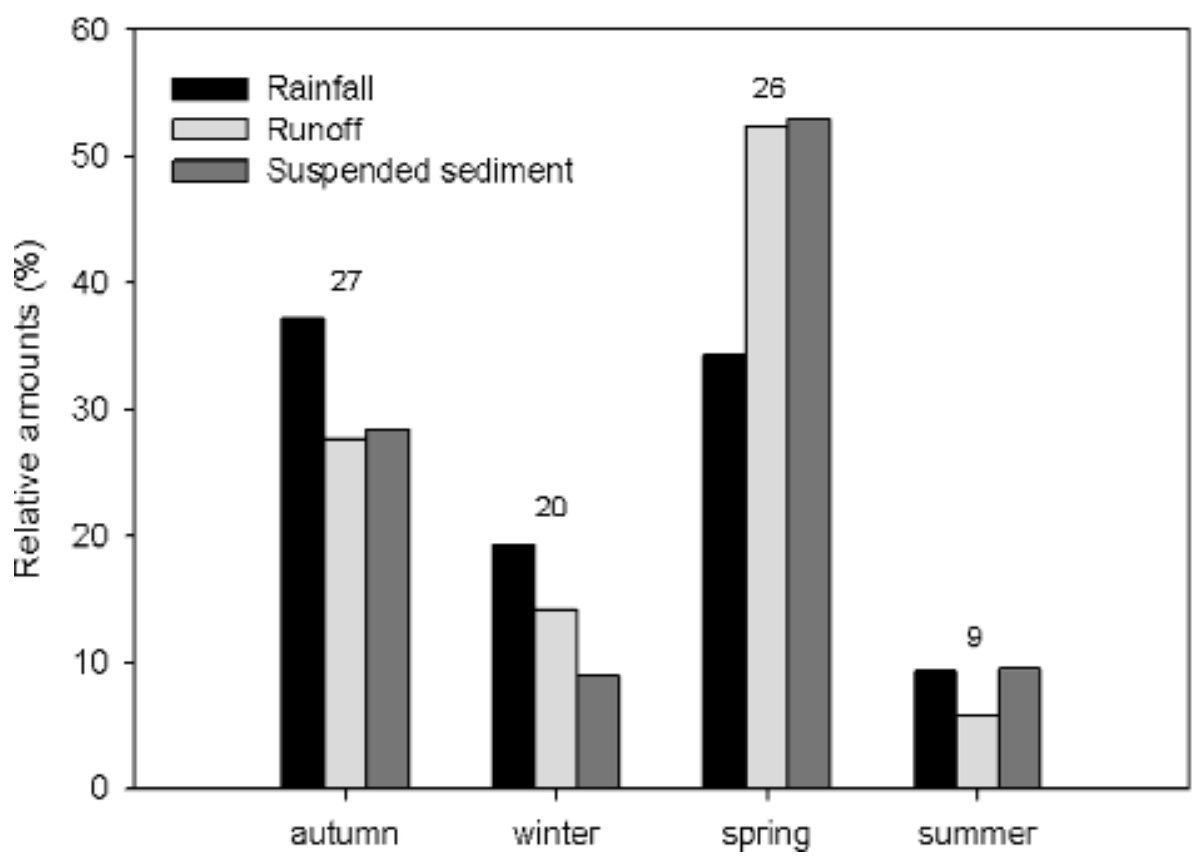

Figure 3. Relative seasonal distribution of rainfall, runoff and suspended sediment yield. The number of floods in each season during the study period is indicated.

The relationships between suspended sediment concentrations (SSC) and rainfall and runoff-related variables at the event scale were studied in several works (LORENTE et al., 2000; SEEGER et al., 2004; LANA-RENAULT et al., 2007b; LANA-RENAULT \& REGÜÉS, 2009) that demonstrated the important 
role played by the rainfall intensity and the base flow in the sediment response at the outlet of the catchment. As shown in Table 2, the peak of SSC was strongly influenced by rainfall and rainfall intensity $(R=0.63$ and $R=$ 0.51 , respectively), suggesting the importance of erosion processes on nonvegetated areas, and probably sediment mobilization by splash (TORRI et al., 1999). The peak flow and the SSC were also positively correlated $(R=0.48)$, reflecting the role played by intense flood events in the sediment response of the catchment. The SSC showed a significant and negative correlation with the base flow discharge at the start of the event $(R=-0.37)$, indicating the occurrence of dilution processes when the catchment is wet (higher base flow discharge values), probably due to the addition of clean water (free of sediment) to the channel (WALLING \& WEBB, 1982; GALLART et al., 1998).

Table 2. Linear correlation coefficients between maximum suspended sediment concentration $\left(\mathrm{SSC}_{\max }\right)$, and rainfall depth (P), 5-min rainfall intensity (IP5), runoff $(\mathrm{R})$, peak flow discharge $\left(Q_{\max }\right)$ and base flow at the start of the event $\left(\mathrm{Q}_{0}\right)$. All the correlations were considered significant at the 0.01 level.

\begin{tabular}{|ccccc|}
\hline & $P(\mathrm{~mm})$ & $I P 5\left(\mathrm{~mm} \mathrm{~h}^{-1}\right)$ & $Q_{\max }\left(\mathrm{l} \mathrm{s}^{-2} \mathrm{~km}^{-2}\right)$ & $Q_{0}\left(\mathrm{l} \mathrm{s}^{-1} \mathrm{~km}^{-2}\right)$ \\
\hline $\mathrm{CSS}_{\max }\left(\mathrm{g} \mathrm{l}^{-1}\right)$ & 0,63 & 0,51 & 0,48 & $-0,37$ \\
\hline
\end{tabular}

\subsection{Assessing the sediment response in relation to runoff generation}

Using information of rainfall, runoff and water table dynamics, LANARENAULT et al. (2007a) identified three main types of flood events associated to different dominant processes of runoff generation in the catchment. Figure 4 reproduces the three type of events together with their corresponding sediment response. The piezometers $\mathrm{w} 7, \mathrm{w} 8$ and $\mathrm{w} 9$ have contrasting topographic locations and dried less frequently, thus they were used to characterize the seasonal variability of "general" water-table dynamics. For each flood event, we analysed the relationships between SSC and discharge (Q), based on the hysteretic patterns described by WILLIAMS (1989). Analyses of SSC-Q hysteretic effects during floods usually provide insights into sediment sources and delivery mechanisms operating in catchments. Three hysteretic SSC-Q patterns were found for each flood event (Figure 5), which are consistent with the findings of SEEGER et al. (2004) and LANARENAULT \& REGÜÉS (2009) that showed that the relationships between SSC and $\mathrm{Q}$ during floods was strongly related to the hydrological functioning of the catchment. 

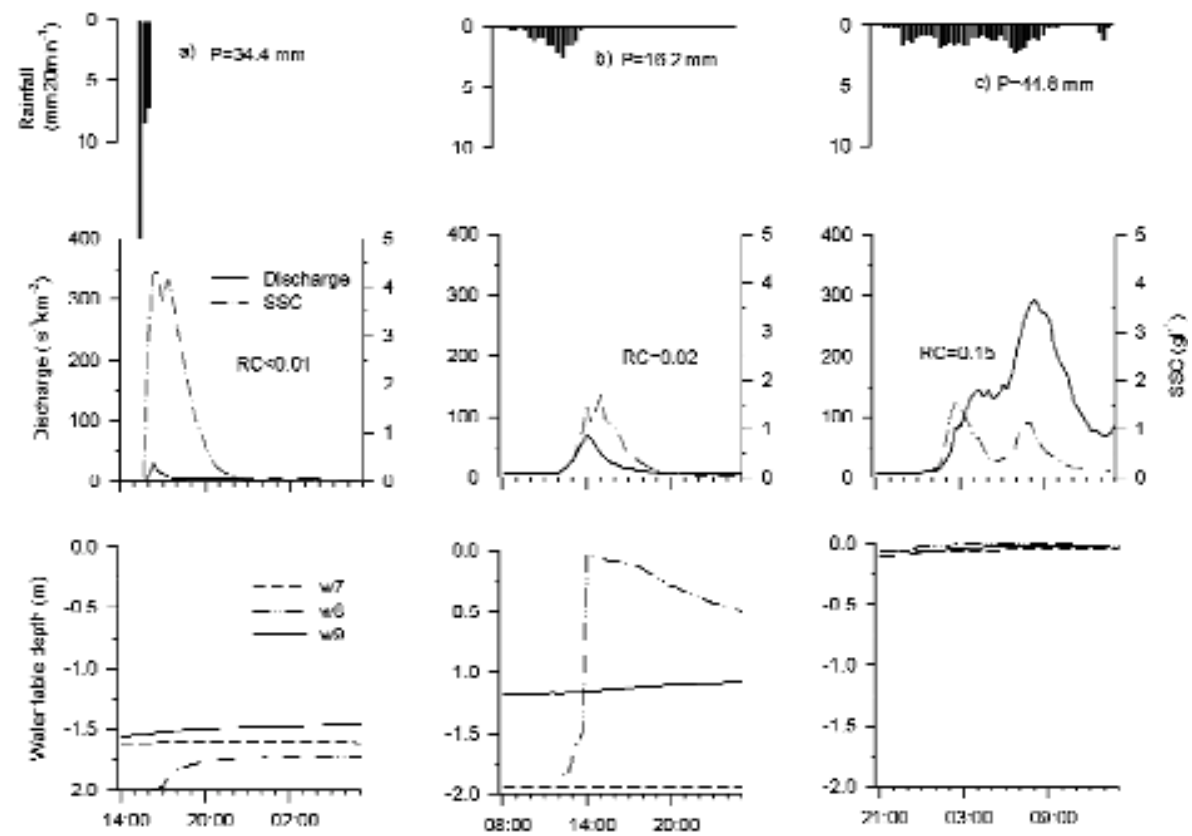

Figure 4. Rainfall, discharge, suspended sediment concentrations (SSC) and water-table dynamics for three representative floods within the Arnás catchment.

Under dry summer conditions (Fig. 4a), there was no base flow at the start of the event and the water table was deep ( $w 7, w 8, w 9<1.5 \mathrm{~m})$. The response of both streamflow and groundwater was very limited, even during a large and intense rainfall event $(\mathrm{P}=34.4 \mathrm{~mm})$. The small storm-flow coefficient $(\mathrm{RC}$ $<0.01)$, the short response time of peakflow, the rapid recession of flow and the high SSC $\left(>4 \mathrm{~g} \mathrm{l}^{-1}\right)$, all suggest that under these conditions the infiltration excess runoff over areas devoid of vegetation close to the channel, is likely to be the only runoff process active within the catchment in response to intense rainfall events. The hysteresis between SSC and Q (Fig. 5a) showed a counterclockwise pattern, with higher values of SSC during the falling limb of the hydrograph. However, the notably reduced hysteretic effect indicates that the SSC-Q ratio was almost constant during the flood, confirming that most probably water and sediment came from the same source areas.

Under transition conditions (wetting-up or the drying-down periods) (Fig. $4 \mathrm{~b}$ ), the water table showed a greater spatial variability and piezometer data indicated that surface saturation was attained in at least parts of the 
catchment. Saturation excess runoff, in combination with a minor contribution from infiltration excess runoff over impervious areas, generated a larger response than that observed during dry conditions $(\mathrm{RC}=0.02)$. The peak of suspended sediment was about $2 \mathrm{~g} \mathrm{l}^{-1}$, and the SSC-Q relationship during the flood (Fig. 5b) showed a larger counter-clockwise hysteretic loop, indicating a delay in the sediment peak. This can be related to the contribution of far sediment sources or/and sediment sources that need more time to react than the saturated areas. The hydrological and sediment response under these conditions reflects a relative enlargement of both water and sediment contributing areas.

Under wet conditions (Fig. 4c), the water table was at the soil surface at the measurement locations, indicating that a large part of the catchment area was saturated at the beginning of the event. Under these conditions, a large rainfall of low intensity $(\mathrm{P}=44.8 \mathrm{~mm})$ produced a higher storm-flow coefficient $(R C=0.15)$. Under these conditions, the streamflow response was usually slow, with a long recession, suggesting a contribution of a slow flow component (i.e., subsurface flow within the soil matrix) in combination with saturation excess runoff. The SSC-Q relationship during the flood (Fig. 5c) showed a clockwise hysteretic loop. The main sediment sources in the catchment are located close to the channel and their area does not vary substantially. As saturation occurs essentially in vegetated areas on the slopes, the lower SSC during the falling stage of the hydrograph is likely to be due to a dilution effect related to the progressive contribution of clean water from these areas. Such a dilution effect can also be caused by an increase in the base flow during flooding (WALLING \& WEBB, 1982). This was clearly evident during floods which were characterized by two or more peak flow discharges. In these cases the second SSC peak was lower than the first, even with similar or higher discharges.

\subsection{Estimation of an annual sediment balance}

By studying bedload transport during floods of different characteristics, LANA-RENAULT \& REGÜÉS (2007) showed that bedload volume strongly depended on peak flow discharge and, to a lesser extent, on effective runoff. The collected bedload data, coupled with field observations, enabled the estimation of a (provisory) discharge threshold for bedload entrainment around $175 \mathrm{l} \mathrm{s}^{-1} \mathrm{~km}^{-2}$, indicating that almost half the events that occurred in the Arnás catchment recorded this type of sediment transport. These authors reported that the proportion of bedload transported at the event scale varied between $10 \%$ and $30 \%$ of the total sediment. 

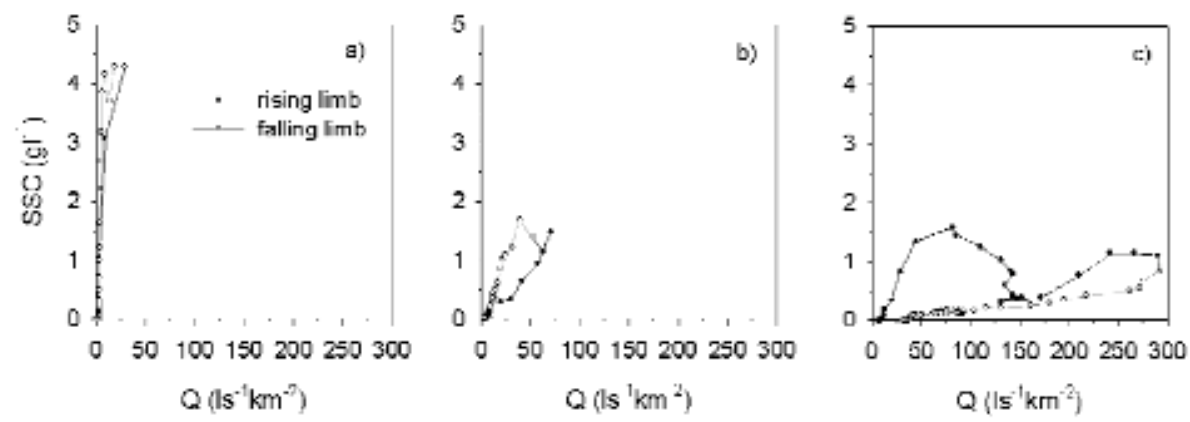

Figure 5. The suspended sediment concentration (SSC) and discharge (Q) hysteresis effect for the three representative floods plotted in Figure 4.

The continuous measurement of conductivity together with the samples collected by the water sampler enabled ARNÁEZ et al. (1999) to estimate an average solute concentration of $250 \mathrm{mg} \mathrm{l}^{-1}$ during floods and $350 \mathrm{mg} \mathrm{l}^{-1}$ during base flow discharge.

Solute, suspended sediment and bedload transport data series showed reliable and complete information for the 2 water years 2003/04 and 2005/ 06 . Table 3 presents the annual values of precipitation, runoff coefficient, and sediment yield for the 2 water years analyzed. The relative bedload, suspended sediment and solutes contributions to the annual sediment output are also presented. The results indicate a prevalence of solutes for the two years. The year 2003/04 was characterized by a higher response in terms of runoff and sediment yield, and flood events were characterized by higher peak flows than in 2005/06 (with median values of 247 vs. $76 \mathrm{ls}^{-1} \mathrm{~km}^{-1}$, respectively). As a consequence, the contribution of suspended sediment in $2003 / 04$ was very close to that of solutes, reflecting the dependence of this type of sediment transport on the occurrence of intense floods. Suspended sediment always dominated at the event scale, with contributions up to $90 \%$ of the total sediment output (LANA-RENAULT \& REGÜÉS, 2007). The contribution of bedload was similar and relatively low during the two years analysed. However, the occurrence of such type of transport suggests that certain torrentiality still prevails in the catchment. 
N. LANA, D. REGÜÉS, E. NADAL, M. P. SERRANO \& J. M. GARCÍA

Table 3. Rainfall, runoff coefficient (RC), and sediment yield for the water years 2003/04 and 2005/06. Percentages indicate the contribution of bedload, suspended sediment and solutes to the annual sediment yield.

\begin{tabular}{|ccccccc|}
\hline Year & $\begin{array}{c}\text { Rainfall } \\
(\mathrm{mm})\end{array}$ & RC ( $\mathrm{mm})$ & $\begin{array}{c}\text { Sediment Yield } \\
\left(\mathrm{Mg} \mathrm{km}^{-2}\right)\end{array}$ & $\begin{array}{c}\text { Bedload } \\
\%\end{array}$ & $\begin{array}{c}\text { Suspended } \\
\text { sediment } \\
\%\end{array}$ & $\begin{array}{c}\text { Solutes } \\
\%\end{array}$ \\
\hline $2003 / 04$ & 958 & 0,33 & 189 & 6 & 46 & 48 \\
$2005 / 06$ & 986 & 0,25 & 123 & 5 & 34 & 61 \\
\hline
\end{tabular}

\section{Conclusions}

In this study we presented the main results of the research carried out in a small catchment intensely cultivated in the past and subsequently abandoned, with respect to its hydrological and sedimentological response.

The hydrological response of the catchment was characterized by a marked seasonality. Discharge was higher in spring, and limited in summer and early autumn, showing a strong dependence on the evolution of the catchment water reserves. The results indicate that the water table recorded a high seasonal dynamics, with a saturation period in winter and spring, and a depletion period in late spring and summer. A great spatial and temporal heterogeneity was detected in the refilling and the drying down of the catchment water reserves, suggesting a higher complexity on its hydrological behaviour during the transition periods. The analysis of rainfall, runoff and water table dynamics at the event scale suggested that runoff generation in the catchment involves a range of several controlling hydrological processes. This processes can occur in different parts of the catchment (i.e., infiltration excess runoff processes over eroded areas, and saturation excess runoff processes over vegetated areas), according to both the antecedent wetness conditions and rainfall characteristics.

The sedimentological response showed a strong seasonality, strongly related to runoff generation. Thus, higher amounts of suspended sediment were found to be exported during spring, when the catchment was hydrologically more active. However, results revealed that the sediment production was mostly controlled by the occurrence of intense but infrequent flood events, increasing the uncertainty for the estimation of long-term sediment yields. Relationships among suspended sediment transport and discharge at the event scale were controlled by the dominant runoff generation process; in particular, by the spatial and seasonal dynamics of the different runoff-contributing areas. An estimation of a sediment balance at 
the annual basis showed that the three types of sediment transport-solutes, suspended sediment and bedload- were relevant in the catchment, adding a degree of complexity in the study of its sedimentological response.

The research carried out in the Arnás catchment showed that an environment affected by traditional farmland practices in the past, with more intensive uses in some areas and more conservative uses in others, now constitutes a "mosaic" of land patches that react differently under varying rainfall and catchment moisture conditions. The vegetation regrowth following farmland abandonment points to a general expansion of shrubs and forest in Mediterranean mountains (MOLINILLO et al., 1997; LASANTA et al., 2005). Research carried out in a nearby forested experimental catchment suggests that the hydrogeomorphic behavior of this kind of environment tends to be more homogeneous, with a clear dominance of subsurface flow and an almost inexistence of sediment sources (SERRANO et al., 2008; GARCÍA-RUIZ et al., 2008). At present, at least one-third of the old cultivated and grazed areas are still covered with grasslands or sparse shrubs (VICENTE-SERRANO et al., 2004). This indicates that heterogeneity in the landscape will remain in the short- and medium-term future and thereby the complexity of the hydrological and sediment transport processes. On going work in the Arnás cathment, especially research into the assessment of dominant runoff generation processes and their relation with catchment wetness dynamics, might help to clarify such complexity and, consequently, predict the trends on water resources and soil erosion in a changing land cover scenario.

\section{Acknowledgements}

Support for this research was provided by the projects: "Processes and sediment balances at different spatial scales in Mediterranean environments: Effects of climate fluctuations and land use changes" (PROBASE, CGL200611619/HID CONSOLIDER), and "Spatiotemporal behaviour and models of the sediment transfer on different land uses" (CETSUS, CGL2007-66644-C0401/HID), both funded by the Spanish Ministry of Education and Science, "Development and validation of coupled hydrological and hydraulic models in catchments at different spatial scales" (PI032/08) funded by the DGA, and ACQWA, supported by the EU-FP7 (www.acqwa.ch) under Contract $\mathrm{Nr}$ 212250. Monitoring of the catchment was supported by an agreement between the CSIC and the Spanish Ministry of Environment (RESEL). The first author benefited from a research contract (I+D+I 2008-2011 National Program), funded by the Spanish Ministry of Education and Science. 


\section{References}

ARNÁEZ, J., MARTÍ-BONO, C., BEGUERÍA, S., LORENTE, A., ERREA, M. P. \& GARCÍA-RUIZ, J. M., 1999. Factores en la generación de crecidas en una cuenca de campos abandonados, Pirineo Central español. Cuadernos de Investigación Geográfica, 25: 7-24.

BEGUERÎA, S., LÓPEZ-MORENO, J. I., GÓMEZ-VILLAR, A., RUBIO, V., LANA-RENAULT, N. \& GARCÍA-RUIZ, J. M., 2006. Fluvial adjustments to soil erosion and plant cover changes in the Central Spanish Pyrenees. Geografiska Annaler, 88A: 177-186.

GALLART, F., LATRON, J. \& REGÜÉS, D., 1998. Hydrological and erosion processes in the research catchments of Vallcebre (Pyrenees). In: FAVISMORTLOCK, J. (ed.) Modelling Soil Erosion by Water., pp. 503-511. Springer-Verlag.

GALLART, F., BALASCH, J. C, REGÜÉS, D., SOLER, M. \& CASTELLTORT, X., 2005. Catchment dynamics in a Mediterranean mountain environment. The Vallcebre research basins (southeastern Pyrenees) II: temporal and spatial dynamics of erosion and stream sediment transport. In: GARCIA, C. \& BATALLA, R.J. (eds.) Catchment dynamics and River Processes: Mediterranean and other Climate Regions, pp. 17-29. Elsevier, Amsterdam.

GARCÍA-RUIZ, J.M. \& LASANTA, T., 1990. Land-use changes in the Spanish Pyrenees. Mountain Research and Development, 10(3): 267-279.

GARCÍA-RUIZ, J. M, LANA-RENAULT, N., BEGUERÍA, S., LASANTA, T, REGÜÉS, D, NADAL-ROMERO, E., SERRANO-MUELA, P., LÓPEZ MORENO J. I., ALVERA, B., MARTÍ-BONO, C. \& ALATORRE, L. C. (submitted). From plot to regional scales: interactions of slope and catchment hydrological and geomorphic processes in relation to vegetation regrowth in the Spanish Pyrenees. Geomorphology.

GARCÍA-RUIZ, J. M., REGÜÉS, D., ALVERA, B., LANA-RENAULT, N., SERRANO-MUELA, P., NADAL-ROMERO, E., NAVAS, A., LATRON, J. \& MARTÍ-BONO, C. (2008). Plant cover, flood generation and sediment transport at catchment scale: a gradient of experimental catchments in the central Pyrenees. Journal of Hydrology, 356: 245-260.

GARCÍA-RUIZ, J. M, ARNÁEZ, J., BEGUERÍA, S., SEEGER, M., MARTÍ, C., REGÜÉS, D., LANA-RENAULT, N. \& WHITE, S., 2005. Flood generation in an intensively disturbed, abandoned farmland catchment, Central Spanish Pyrenees. Catena, 59: 79-92.

GONZÁLEZ, C., GARCÍA-RUIZ, J. M., MARTÍ, C., WHITE, S., ERREA, M. P. \& ARNÁEZ, J., 1997. Sediment sources in a small, abandoned farmland catchment, Central Spanish Pyrenees. Physics and Chemistry of the Earth, 22(3-4): 291-293. 
STEAMFLOW RESPONSE AND SEDIMENT YIELD AFTER FARMLAND ABANDONMENT:...

GONZÁLEZ-HIDALGO, J. C., PEÑA-MONNE, J. L. \& DE LUIS, M., 2007. A review of daily soil erosion in Western Mediterranean areas. Catena, 71(2): 193-199.

LANA-RENAULT, N. \& REGÜÉS, D., 2007. Bedload transport under different flow conditions in a human-disturbed catchment in the Central Spanish Pyrenees. Catena, 71: 155-163.

LANA-RENAULT, N. \& REGÜÉS, D., 2009. Seasonal patterns of suspended sediment transport in an abandoned farmland catchment in the Central Spanish Pyrenees. Earth Surface Processes and Landforms, 34: 1291-1301.

LANA-RENAULT, N., LATRON, J. \& REGÜÉS, D., 2007a. Streamflow response and water-table dynamics in a sub-Mediterranean research catchment (Central Pyrenees). Journal of Hydrology, 347: 497-507.

LANA-RENAULT, N., REGÜÉS, D., MARTÍ-BONO, C., BEGUERÍA, B., LATRON, J., NADAL, E., SERRANO, P. \& GARCÍA-RUIZ, J. M., 2007b. Temporal variability in the relationships between precipitation, discharge and suspended sediment concentration in a Mediterranean mountain catchment. Nordic Hydrology, 38(2): 139-150.

LASANTA, T., 1988. The process of desertion of cultivated areas in the Central Spanish Pyrenees. Pirineos, 132: 15-36.

LASANTA, T. \& VICENTE-SERRANO, S., 2007. Cambios en la cubierta vegetal en el Pirineo aragonés en los últimos 50 años. Pirineos, 162: 125154.

LASANTA, T., VICENTE-SERRANO, S. M. \& CUADRAT, J. M., 2005. Mountain Mediterranean landscape evolution caused by the abandonment of traditional primary activities: a study of the Spanish Central Pyrenees. Applied Geography, 25: 47-65.

LÓPEZ-MORENO, J. I., BENISTON, M. \& GARCÍA-RUIZ, J. M., 2008. Environmental change and water management in the Pyrenees: Facts and future perspectives for Mediterranean mountains. Global and Planetary Change, 61: 300-312.

LORENTE, A., MARTÍ, C., BEGUERÍA, S., ARNÁEZ, J. \& GARCÍA-RUIZ, J. M., 2000. La exportación de sedimento en suspensión en una cuenca de campos abandonados, Pirineo Central. Cuaternario y Geomorfología, 14(1-2): 21-34.

MOLINILLO, M., LASANTA, T. \& GARCÍA-RUIZ, J. M., 1997. Managing mountainous degraded landscapes after farmland abandonment in the Central Spanish Pyrenees. Environmental Management, 21: 587-598.

NADAL-ROMERO, E., LATRON, J., MARTÍ-BONO, C. \& REGÜÉS, D., 2008. Temporal distribution of suspended sediment transport in a humid Mediterranean badland area: The Araguás catchment, Central Pyrenees. Geomorphology, 97: 601-610. 
NAVAS, A., MACHÍN, J. \& SOTO, J., 2005. Assessing soil erosion in a Pyrenean mountain catchment using GIS and fallout 137Cs. Agriculture, Ecosystems and Environment, 105 (3): 493-506.

REGÜÉS, D., BALASCH, J. C., CASTELLTORT, X., SOLER, M. \& GALLART, F., 2000. Relación entre las tendencias temporales de producción de sedimentos y las condiciones climáticas en una pequeña cuenca de montaña mediterránea (Vallcebre, Pirineos orientales). Cuadernos de Investigación Geográfica, 26: 41-65.

SEEGER, M., ERREA, M. P., BEGUERÍA, S., ARNÁEZ, J., MARTÍ, C. \& GARCÍA-RUIZ, J. M., 2004. Catchment soil moisture and rainfall characteristics as determinant factors for discharge/suspended sediment hysteretic loops in a small catchment in the Spanish Pyrenees. Journal of Hydrology, 288: 299-311.

SERRANO-MUELA, M. P., LANA-RENAULT, N., NADAL-ROMERO, E., REGÜÉS, D., LATRON, J., MARTÍ-BONO, C. \& GARCÍA-RUIZ, J. M., 2008. Forests and water resources in Mediterranean mountains: The case of the Spanish Pyrenees. Mountain Research and Development, 28 (3-4): 279285.

SOLER, M., REGÜÉS, D., LATRON, J. \& GALLART, F., 2007. Frequencymagnitude relationships for precipitation, stream flow and sediment load events in a small Mediterranean basin (Vallcebre basin, Eastern Pyrenees). Catena, 71(1): 164-171.

TAILLEFUMIER, F. \& PIÉGAY, H., 2003. Contemporary land use changes in prealpine Mediterranean mountains: a multivariate GIS-based approach applied to two municipalities in the Southern French Prealps. Catena, 51(34): 267-296.

TORRI, D., REGÜÉS, D., PELLEGRINI, S. \& BAZZOFI, P., 1999. Within-storm soil surface dynamics and erosive effects of rainstorms. Catena, 38(2): 131150.

VICENTE-SERRANO, S. M., LASANTA, T. \& ROMO, M., 2004. Analysis of spatial and temporal evolution of vegetation cover in the Spanish Central Pyrenees: Role of human management. Environmental Management, 34 (6): 802-818

WALLING, D.E. \& WEBB, B. W., 1982. Sediment availability and the prediction of storm-period sediment yields. IAHS Publication, 137: 327-337.

WILLIAMS, G.P., 1989. Sediment concentration versus water discharge during single hydrological events in rivers. Journal of Hydrology, 111: 89106. 